\title{
海外のリーフ海岸保全事業におけるモニタリング調査 および維持管理上の課題
}

\author{
MONITORING STUDY FOR OVERSEAS BEACH CONSERVATION PROJECT \\ AND PROBLEM ON MAINTENANCE AND OPERATION SYSTEM
}

\author{
大中 晋 1 - 遠藤秀文 $2 \cdot$ 吉井一郎 2 \\ Susumu ONAKA, Shubun ENDO, and Ichiro YOSHII \\ 1正会員 工修 日本工営㑣コンサルタント海外事業部（テ102-0083 東京都千代田区靝町4-2) \\ 2正会員日本工営侏コンサルタント海外事業部（テ102-0083 東京都千代田区䊁町4-2）
}

\begin{abstract}
Long-term shoreline monitoring survey with more than three-years has been carried out after completion of beach nourishment in Sanur and Nusa Dua Beaches in Bali Island. The objective of the monitoring work is to know the beach behavior after initial beach filling and to prepare the future maintenance plan including the supplementary beach filling. It was observed that the beach reached in stable condition after half years although some unpredicted beach change appeared. After completion of project, some undesirable problems came into surfaced concerning maintenance and operation system.
\end{abstract}

Key Words : Beach Nourishment, Beach Erosion, Coral Reef, Monitoring Survey, Maintenance

\section{1.はじめに}

インドネシア国バリ島の観光地海岸であるサ ヌールおよびヌサドア海岸では,わが国の援助に よる海岸保全事業が実施されてきた。これは, 1970年代より顕在化しつつあったサンゴ礁海岸の 侵食問題に対処するために，養浜工による砂浜の 回復を図乃うとしたものであった。我が国での リーフ海岸上での大規模な養浜事例は限られる上 に，養浜後の海浜の挙動に関する報告事例は限ら れている.このため, 養浜事業で重要と考えられ る，初期養浜後の養浜砂の追加投入を含めた維持 管理計画の策定に対して参考となる現地事例は数 少ない。サヌールおよびヌサドア海岸では, 養浜 砂の投入から既に 3 年以上経過し, 投入直後から 海岸モニタリング調査が開始され, 現在も継続実 施中である。そこで本研究は，両海岸のうち，サ ヌール海岸で実施されてきた過去 3 年間における 養浜後の海岸モニタリング調査結果を用いて, 養 浜後の海岸挙動および養浜砂の歩留まり状況を明 らかにするとともに，養浜事業実施後に両海岸で 顕在化しつつある維持管理上の問題点・課題点に ついて示す.

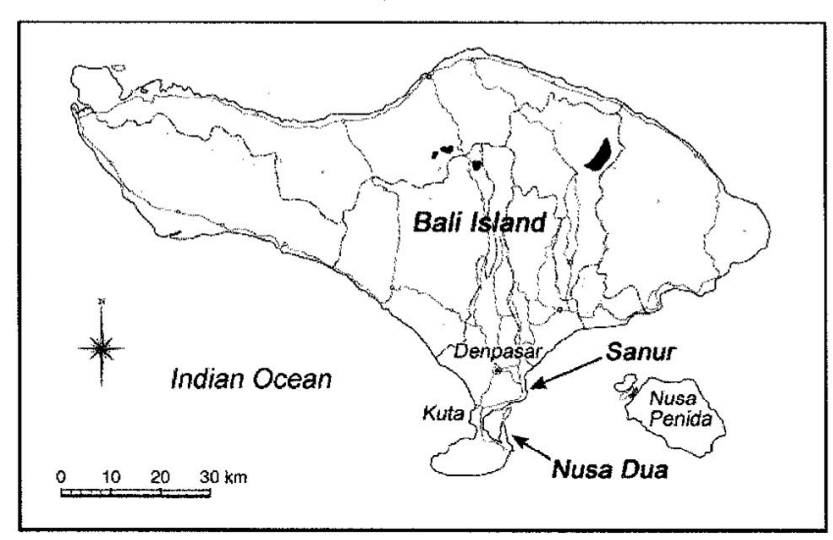

図-1 バリ島サヌール海岸とヌサドア海岸の位置

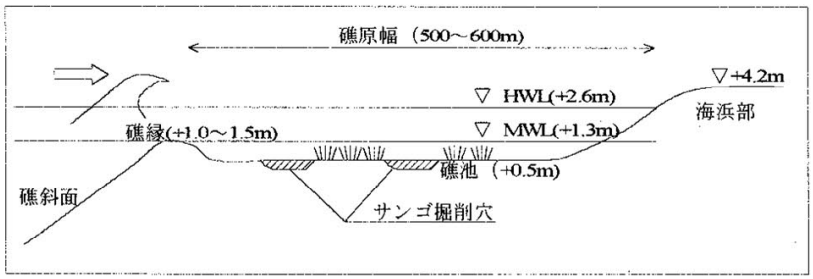

図-2 両海岸のリーフ断面状況 


\section{2. 調査の概要}

\section{（1）プロジェクトの概要}

養浜事業の対象海岸は，バリ島内の有名なサンゴ 礁海岸であるサヌール海岸とヌサドア海岸である. 図-1に示拉よに，両海岸ともバリ島南東部に位置 し, サヌール海岸は総延長が約 $6.2 \mathrm{~km}$, ヌサドア海 岸は約 $5.6 \mathrm{~km}$ である。サール海岸の平均的なリー フ幅は $600 \mathrm{~m} ，$ ヌサドア海岸は約 $500 \mathrm{~m} ゙$ ある。これら の海岸の潮位はHWL $+2.6 \mathrm{~m} ， \mathrm{LWL} \pm 0.0 \mathrm{~m}$ にあり，平均 的なリーフ上水深は+0.5mである（図-2）。両海岸 では，観光資源として重要な砂浜の復元を目的とし た養浜工事が2000年より開始され，2004年10月に完 了した。この中で養浜砂の投入は2003年10月から12 月にかけて実施された ${ }^{1)}$ 。これより養浜砂が投入さ れてから現在まで既に3年半が経過したことになる。 両海岸における海岸保全対策の基本的な考え方は, 養浜工に流出防止施設としての突堤, ヘッドランド を組み合わせた静的安定化を図るものである。サ ヌール海岸では約 30 万 $\mathrm{m}^{3} の$ 養浜投入と，合わせて 13 基の突堤・ヘッドランド，および 1 基の離岸堤を設 置した（図-1）。一方サドア海岸においては約35 万 $\mathrm{m}^{3}$ の養浜投入と，13基の突堤・ヘッドランドを設 置した．投入された養浜砂は，ヌサドア海岸沖の水 深的20-30m地点の海底より自航式浚渫船にて採取さ れ，両海岸に運搬後，排砂管を用いてリーフ内に投 人された。

\section{（2）海岸線モニタリング調查}

海岸線モニタリング調査は, 養浜後の海浜挙動を 把握し, 今後の追加養浜投入を含む維持管理計画を 策定することを目的に，養浜直後から現在まで継続 的に実施されている。モニタリングの頻度は，養浜 実施直後から半年間は 1 ケ月毎, その後 2 年後まで は 3 ヶ月每, 2 年後以降は半年毎に実施している.
主なモニタリング項目は，汀線測量および定点写真 撮影である. 汀線測量は，沿岸方向の10〜20m毎に 測線を設け，各測線上での縦断測量を実施している。

\section{3. 海岸特性および養浜形状の設定}

サヌールおよびヌサドア海岸の両海岸とも，バリ 島南部の東側に位置し隣接している．ヌリドア海岸 はサヌール海岸より南側に位置し，南方より入射す るインド洋からの入射波は，ヌサドア海岸の方が若 干高くなる。両海岸とも卓越沿岸漂砂方向は, この 南からの入射波の影響により，北向きとなる、しか しながら，サヌール海岸南側（写真-1中のG9付近） では，沖側のリーフギャップの地形に対応して海岸 線が大きく凸型に屈曲するため, 波の入射方向に対 する海岸線方向が，このリーフギャップを境に北側 と南側とで大きく異なる。これより本論では，両海 岸のうちサヌール海岸について着目し, 特にリーフ ギャップ南側と北側における養浜後の海浜挙動につ いて示す.

\section{（1） サヌール海岸の波浪，地形および漂砂特性}

サヌール海岸で，過去に実施された約半年間での 入射波浪調査より得られた当海岸での波浪特性はつ ぎのとおりである。リーフ外での入射波高 $\left(\mathrm{H}_{1 / 3}\right)$ は, $0.4 \sim 1.5 \mathrm{~m}$ 程度の範囲に分布し, 平均的には $0.6 \mathrm{~m}$ 程度である。周期 $\left(\mathrm{T}_{1 / 3}\right)$ は $6 \sim 14 \mathrm{~s}$ 程度の範 囲に分布し, 平均的には $8.5 \mathrm{~s}$ 程度である. 当地点 では乾季 ( 5 月〜10月) と雨季 (11月〜 月 月) とで 風況および波浪特性が異なり，乾季には東からの貿 易風が卓越し，バリ島東側に位置する当海岸では波 高が高くなる。波向は，乾季と雨季とでそれほど違 いはなく，年間を通じての主要な波向としてはESE からSEである。

リーフ上の波浪は，リーフの存在によりその特性

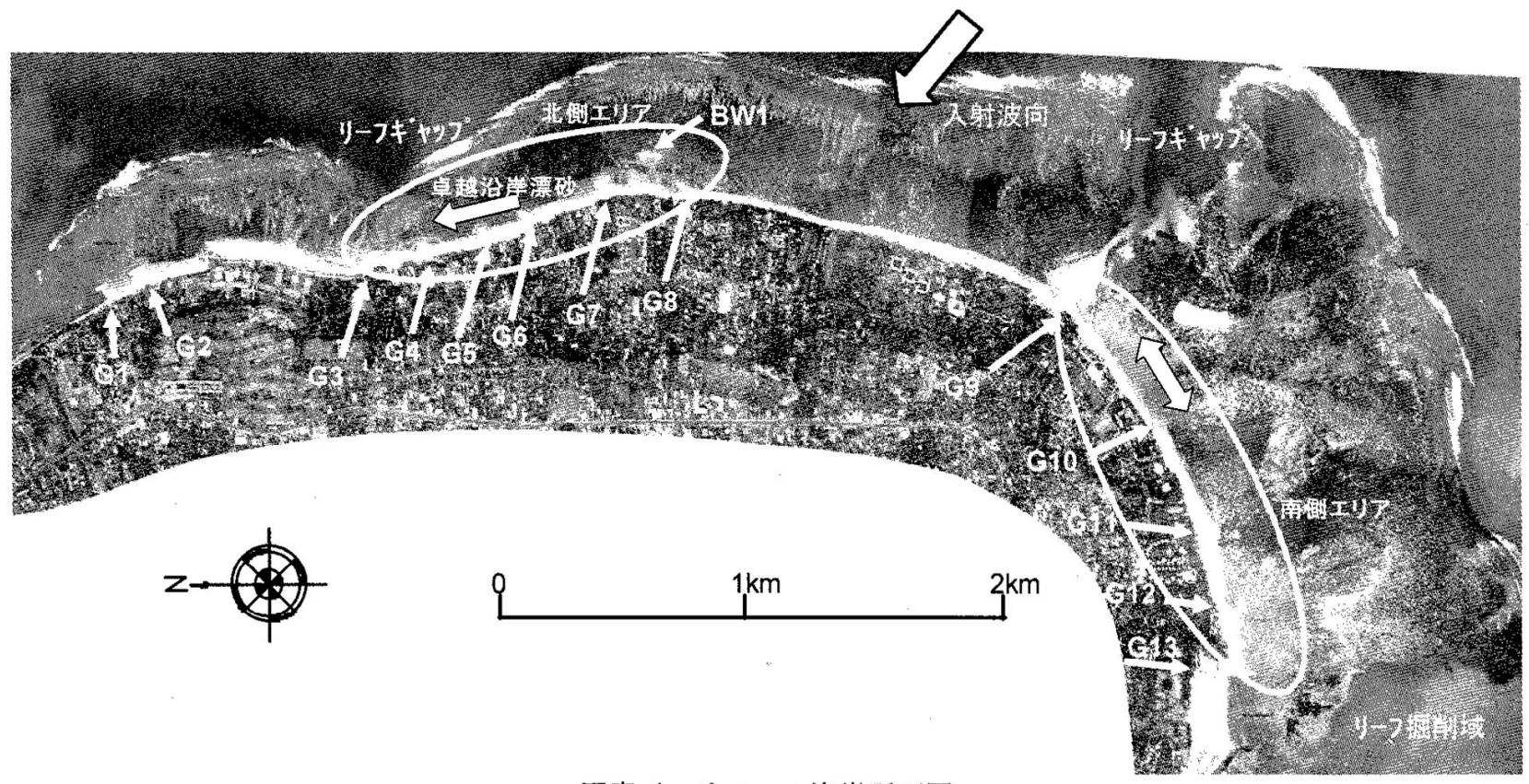

写真-1 サヌール海岸平面図 
は大きく変わり，リーフエッジで一度砕波するため に波高は減少し，周期は短くなる。リーフ上の波高 変化はリーフ上水深およびリーフ幅に大きく依存す る. 写真-1に示す北側エリアのリーフ幅が 200〜 $400 \mathrm{~m}$ 程度の地点においては, リーフ上の波高はリ一 フ上水深の $0.2 \sim 0.3$ 程度, リーフ幅が $1.2 \mathrm{~km}$ 程度と なる南側では0.1程度である。またリーフ上では, リーフ内外水位差に伴う流れが潮位による水位変化 に応じて生じ，特にリーフギャップを通してリ一フ 内外の海水の流出入が顕著となることから, その付 近で流れも顕著となる。

サヌール海岸北側では, 北に向かう沿岸漂砂が存 在し, 過去の汀線変化の実態解析結果より, 沿岸漂 砂量として $6,000 \mathrm{~m}^{3} / \mathrm{yr}$ と推定された。一方南側には 顕著なリーフギャップが存在し，このリーフギャッ プを境に, 南側エリアでは海岸線は大きく屈曲し, 北側エリアの海岸線方向である南北方向から北東一 南西方向に変化する. この上うな海岸線方向の変化 により，南側エリアでは，以前から北側エリアで見 られるような明らかな北向きの漂砂移動を示寸海浜 応答状況が見られなかった. さらに本プロジェクト 計画後に実施されたサヌール海岸南端でのリゾート 開発に伴う大規模なリーフ掘削により, サヌール海 岸南側エリアの漂砂特性は以前の状態から変わった 可能性があった.

\section{（2）初期養浜形状の設定}

盖浜平面形状は, 盖浜後の変形を最小限とするた め, 想定される波の入射方向に直角方向となるよう, 養浜前の汀線形状に沿う形を基本とし, 将来予測形 状は汀線変化予測シミュレーションを実施し, 確認 した.また，ヘッドの存在による局所的な汀線形状 は, $\mathrm{HSU}^{2)} の$ 式を用いて修正を加えた。必要養浜幅は, 侵食前の1970年代当時の汀線位置まで復元すること を基本とし, 平均的な養浜幅として，20m程度と設 定した. 投入した養浜砂は, 養浜前の当海岸の粒度 分布, 平均粒径 (D50 $=0.6 \mathrm{~mm}$ 程度) に等しい諸元を 持つことを確認している. これより断面形状につい ては, 基本的には養浜前の当海岸の自然海浜部にお ける諸元と同様, 前浜勾配については $1: 8 \sim 1: 10$, バーム高については+3.6mに設定した。

\section{4. 養浜後の海浜挙動}

\section{（1）北側エリアについて}

はじめにサヌール海岸北側エリア（写真-1）にお ける海浜挙動について示す. 写真-2は, 北側エリア に設置された 6 本の突堤群（G3〜G8）の各形状・配 置と, 2006年 8 月時点における汀線状況を示したも のである。なお， G7〜 G8突堤間には堤長約 $70 \mathrm{~m}$ の離 岸堤（BW1）が設置されている. 図-3は，このエリ アにおける2006年12月までの約 3 年間における汀線 変化量を示す。縦軸の汀線変化量は, 養浜直後の 2003年12月を基準としたときの，+2.6m高さ（HWL）
における汀線変化量を示すものである。この付近の リーフ幅は200〜 500m程度と, サヌール海岸の中で もリ一フ幅が狭いエリアである，特にG3〜G4突堤閒 の沖側には小規模なリーフギャップが存在し, この 付近でリーフ幅は最も狭まり，200m程度である。養 浜前の当エリアは, ほぼ全域にわたり護岸で固めら れ，浜はほとんど消失した状態であったが1)，養浜 前の海岸状況から, 北向き沿岸漂砂が存在すること が確認されていた。 図-3の養浜後の汀線変化状況か らも，ほぼ一律の北向き沿岸漂砂の存在が確認でき る. 養浜投入から約半年後の 2004 年 7 月以降, 顕著 な変化は見られず, 海浜はほぼ安定した状態を維持 している. G3〜G7突堤の 4 区画のすべてにおいて， 初期汀線から南側で後退, 北側で前進（もしくは変 化なし）していることから, 設定した初期養浜形状 よりも，より角度を持った汀線形が安定形状であっ たといえる. 離岸堤の存在するG7〜G8突堤区間では,
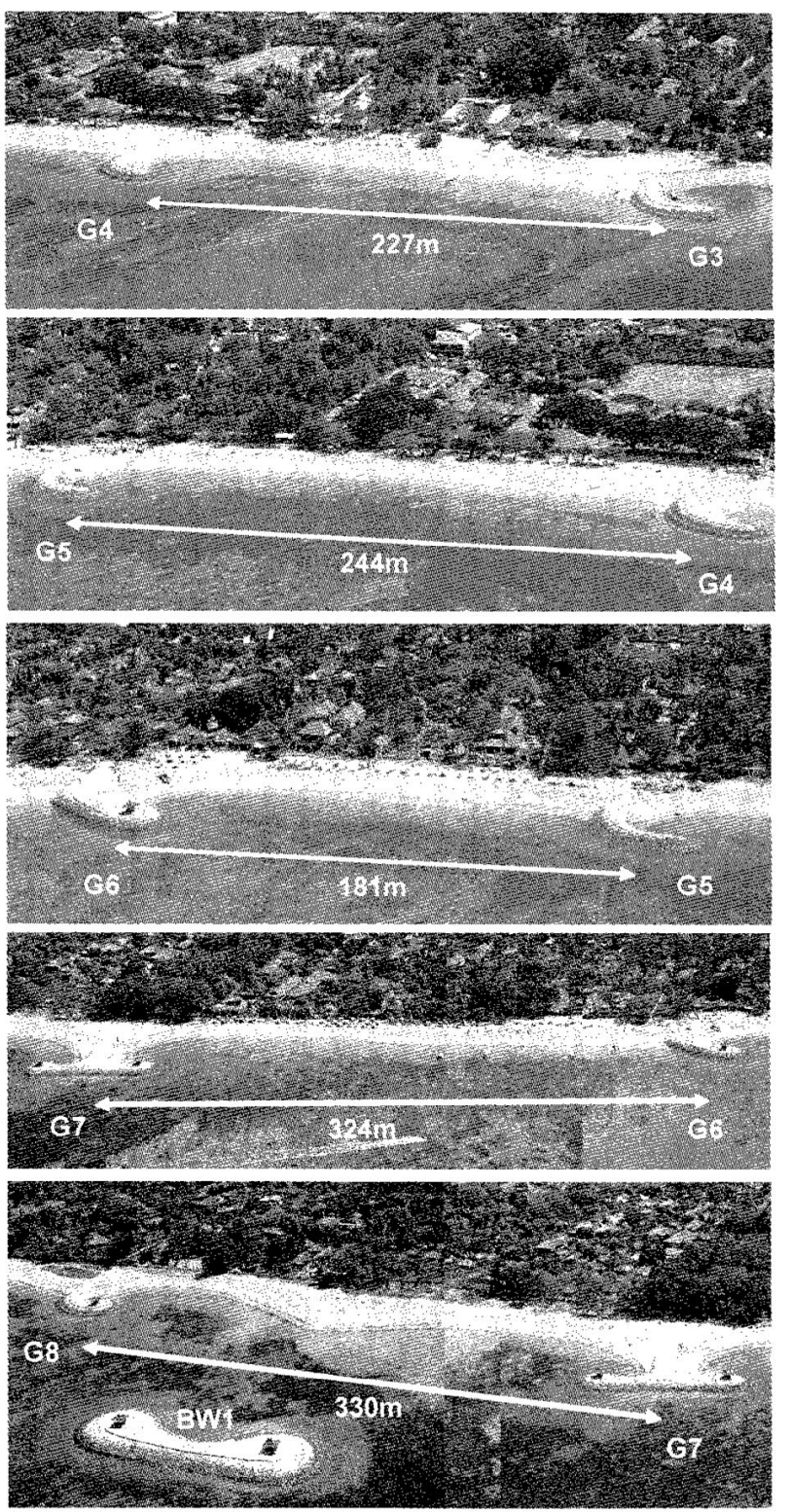

写真-2 北側エリアの突堤形状と汀線状況 (2006年 8月) 


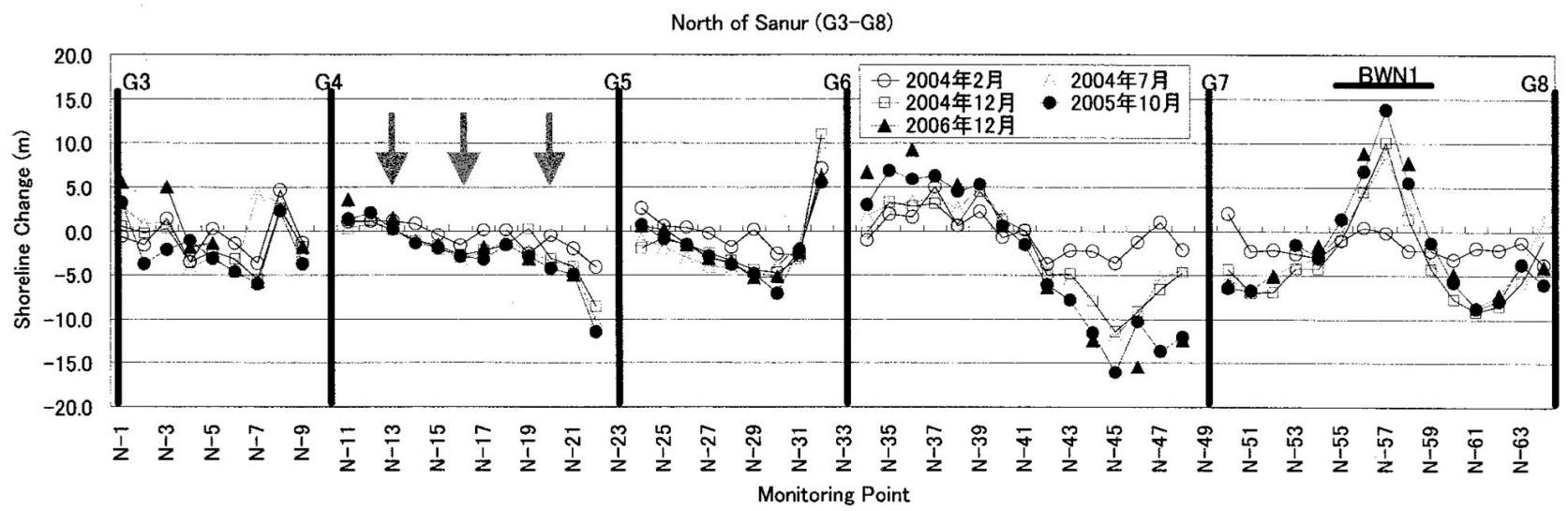

図-3 サヌール海岸北側エリアにおける養浜後の汀線変化
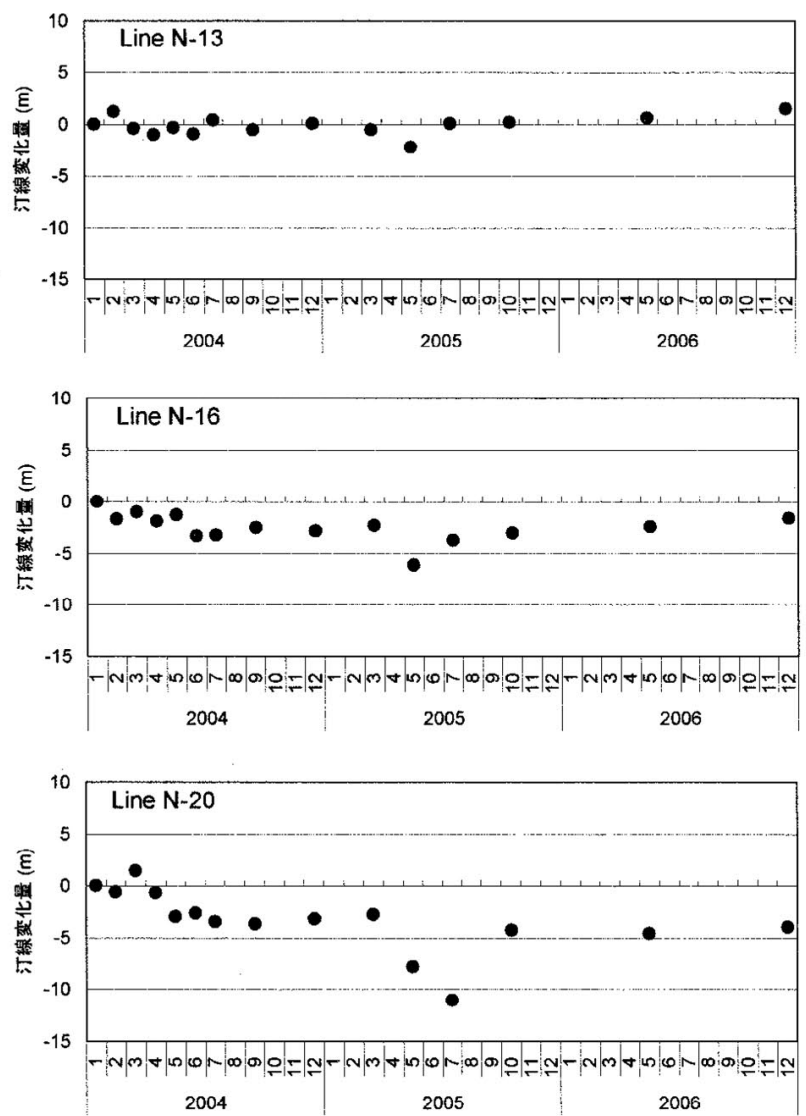

図-4 G4-G5突堤間の汀線経年変化

離岸堤背後のトンボロ形成のために，乙の両側の汀 線が後退しているが，左右の非対称性が見られる. このことからも, 北向き沿岸漂砂の存在が確認され る.

つぎに汀線変化の経年的変化を見るために，G4G5区間内において，図-3に示すように中央部および 左右の代表 3 測線での汀線変化量の経年変化を示し たものが図-4である。これより養浜直後の初期変形 は，養浜砂投入後ほぼ半年程度で安定化している様 子が見られる. サヌール海岸は通常乾季（ 5 月〜 10 月）に波高が大きくなる傾向となるが，図-5からも 乾季に汀線後退が顕著となる傾向が示されている.
しかし北側の測線ほよ゙，乾季での顕著な汀線後退は 緩和される傾向が見られる。これより，乾季では波 浪エネルギーの増大により，一部の砂は区間外に流 出するとともに，北側に砂が押されたと考えられる.

\section{（2）南側エリアについて}

つぎにサヌール海岸南側エリアにおける海浜挙動 について示す。北側と同様に南側エリアに設置され た 5 本の突堤群 (G9〜 G13) の各形状・配置と, 2006年 8 月の汀線状況を示したものが写真-3であり, このエリアにおける汀線変化量を示したものが図-5 である. 当エリアにおける汀線変化は, 北側エリア で見られたような北方向の沿岸漂砂を示す一律な変 化ではなく，各区間で異なる傾向が見られる，G10G11突堤間では北側での汀線後退と南側での前進, G11-G12間では北側での汀線前進と南側での後退が 生じている。当エリアは, 以前から年閒を通しての 一定方向の沿岸漂砂方向が見られず，季節あるいは 各年により変動している様子が見られた。図一6は, G10-G11突堤間における代表 3 測線における汀線変 化量の経年変化を示すが，北側での経年変化（図一
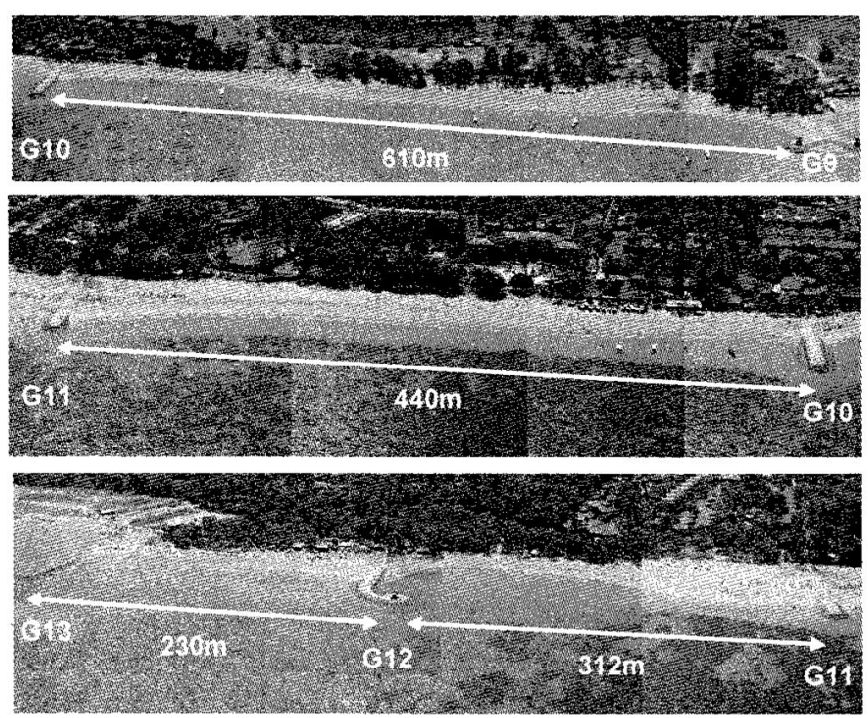

写真-3 南側エリアの塋堤形状と汀線状況 (2006年 8 月) 


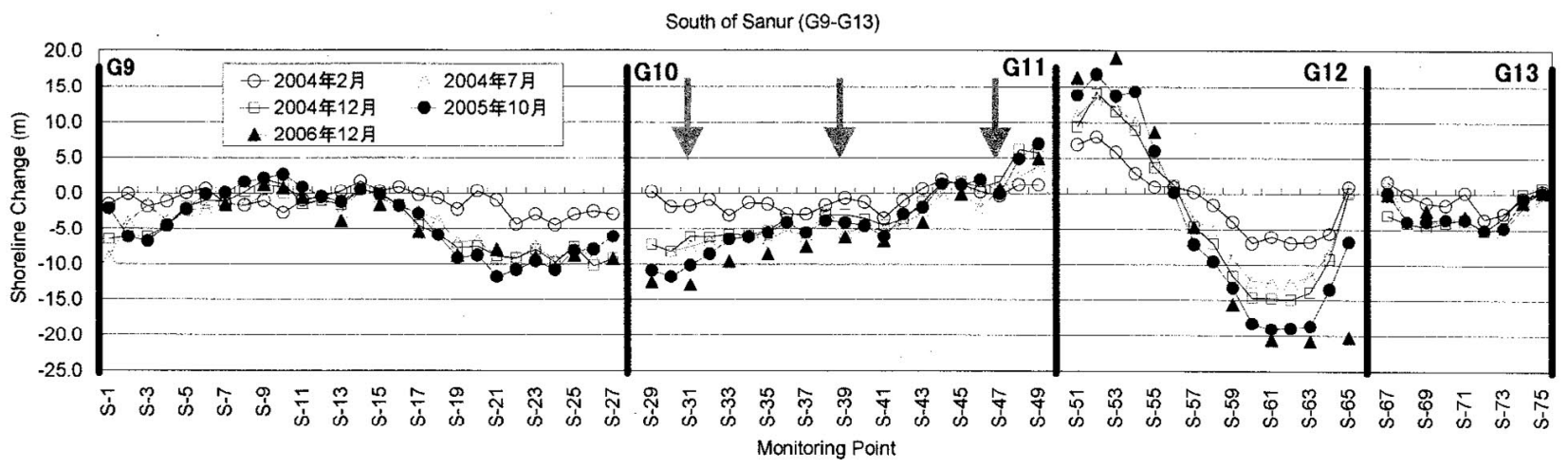

図-5 サヌール海岸南側エリアにおける養浜後の汀線変化
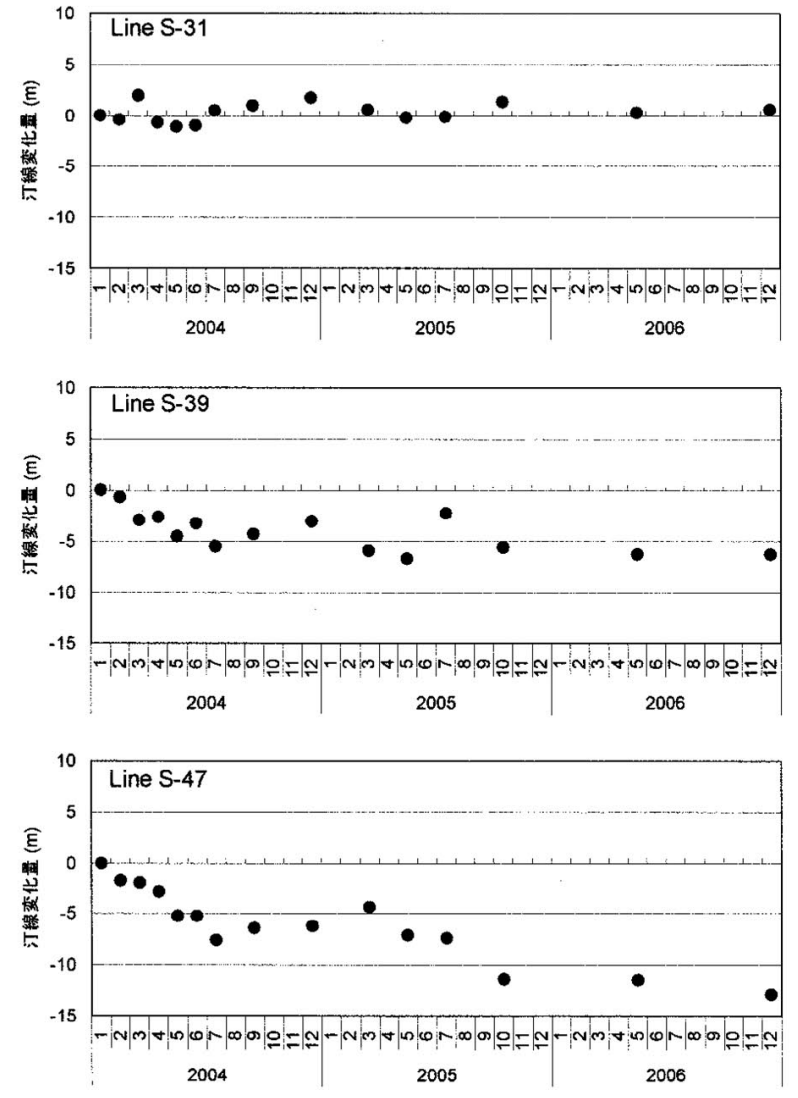

図-6 G10-G11突堤間の汀線経年変化

4）に見られたような明らかな季節特性は見られな い. その要因の 1 つとして，当エリアは北側に比べ てリーフ幅が $1.2 \mathrm{~km}$ 程度と $3 \sim 5$ 倍程度広いために, 北側エリアほど季節の違いによる沖波波浪特性の変 化の影響を受けないと考えられる。また，G11-G12 突堤間で見られる顕著な北側への砂移動は, 南側で のリーフ掘削に伴い，リーフ外からの入射波エネル ギーが他区間に比べて増大している可能性があるこ と，およびリーフ掘削形状に対㐫して局所的な入射 波向の変化が生じたことに起因すると考えられる。

\section{（3）養浜砂の歩留まり状況について}

各測線上での繸断地形変化より計算される海浜土
砂量変化より，区間毎の養浜砂の歩留まり状況を調 べた．その結果，養浜投入から 3 年経過した 2006 年 12月時点で, 北側エリア（図-3）においては 9 割強 程度，また南側エリア（図-5）においては 8 割程度 の歩留まり率が得られた。将来的な維持管理計画を 策定する上で, 今後もデ一夕を蓄積し, より長期間 での歩留まり状況を把握していく必要がある.

\section{5. 海岸管理上の問題点・課題点}

本事業においては，プロジェクトの実施から完了 までは中央政府（公共事業省）の管轄下で実施され る.しかしその後は，地方政府（バリ州政府）に管 理運営も含めて移管されることとなっている。しか し両海岸とも完厂して既に 3 年以上経過しているが, 実際には養浜後の砂浜の管理運営は不明瞭のままで ある.その背景には, インドネシアではバリ島海岸 を含め，海岸域管理に対する法的に定められたもの は存在せず，管理区域，管理責任者，管理方法など が明確にされていないことが挙げられる。したがっ て，書面上では地方政府に移管されることとなって いるものの，実際には地方政府側で，特に維持管理 に関する予算措置や体制作りは行われていない。ま たインドネシア国として，大規模な養浜事業は初め てであることもあり，養浜事業を所定の耐用年数を 持つ一般的な土木施設と同等と考えている関係者が ほとんどであり，追加養浜等を含めた維持管理の必 要性を認識している関係者は極めて少ないのが現状 である。

このような海岸の管理運営体制の不備がプロジェ クト終了後の本海岸に及ぼす影響の一例を示す。リ ゾート海岸であるサヌール，ヌサドア海岸では，法 律上では明言されていないものの，背後にホテルが 立地するプライベートエリアと，それ以外の公共エ リアが混在している，プライベートエリアでは，各 ホテル独自に日々の砂浜の清掃等の維持管理が実施 され，良好な海浜状態が維持されている（写真-4）. 一方公共エリアにおいては，十分な管理がされてお らず放置された状態となっているエリアが多く，海 岸域でのごみや海草類の滞積や，遊歩道を含む陸側 部への砂の堆積等が生じ，海岸を散歩する観光客へ 
の支障も生じている（写真-5）。

バリ島における海岸管理に関する唯一の法的規制 として, 満潮潮位時の水際線から陸側 $25 \mathrm{~m}$ 以内での 一切の構造物の設置が禁止されている。本プロジェ クトでは，陸側に遊歩道を設置しているが，その目 的としては，単に海岸利用面の向上だけでなく，陸 域と海岸域との管理境界の明確化を図ることも含ま れている。ここで遊歩道を境界として海側は官側に よる管理を前提としており，また一切の建築物の設 置を禁止する取り決めとなっている，それにも関わ らず, 復元された砂浜上での違法建築物の設置が数 力所で見られるが，放置された状態となっている (写真-6) .

\section{6. おわりに}

静的安定化を目指したバリ島サヌール，ヌサドア 海岸における盖浜事業は，養浜投入から既に 3 年以 上を経過し，全体的にはほぼ安定した海岸状況を 保っている。しかしながら，一部の箇所では当初の 想定とは異なる海浜応答を示している箇所や, 汀線 後退が未だに生じている箇所も見られる. 今後更に データを蓄積し, 実施後の海岸変化状況に応じた適 切な順灾化管理を実施していく必要があり，プロ ジェクト終了後は相手国政府が引き継いで実施して いく必要がある。

リーフ海岸は, リーフの存在による自然の波浪低 減が得られるために, 養浜工に対して一般の砂浜海 岸と比べて自然条件上の利点を有する。このため, 初期養浜後の追加養浜砂投入を含めた長期的な海岸 維持管理についても, 通常海岸に比べて小さい規模 ですむことが期待でき, 相手国政府で実施できる可 能性は十分あるものと考えられる. しかしそのため には, 相手国による継続的な海岸モニタリングの実 施とその解析 - 判断能力の構築, 管理運営体制の確 立等, ソフト面の充実が不可欠である. そのような 体制を如何に構築していくかが，今後取り組んでい かなければならない課題である。

\section{参考文献}

1）大中 晋・遠藤秀文・宇多高明・吉井一郎：リ一フ海 岸における養浜工の設計・施工および養浜後の海浜応 答，第30回海洋開発論文集，pp. 475-480，2005.

2) Hsu, J. R. C. and C. Evans : Parabolic bay shapes and applications, Proc. Intn. Civ. Engrs, Part 2, 97, pp. 557-570, 1989.

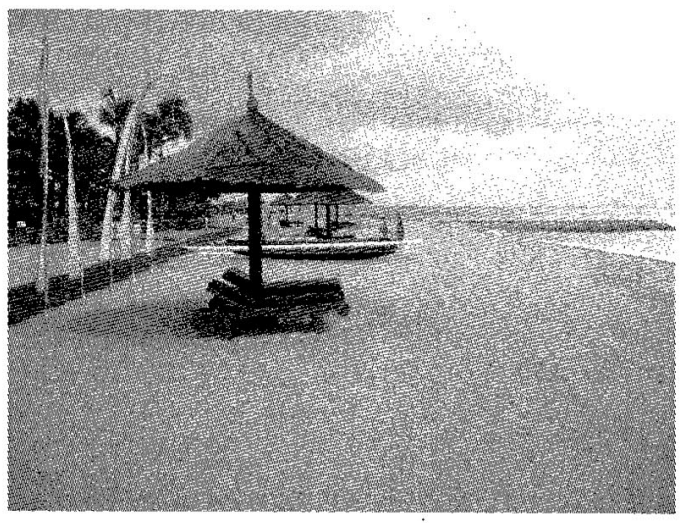

写真-4 プライベートエリアの良好な整備状況

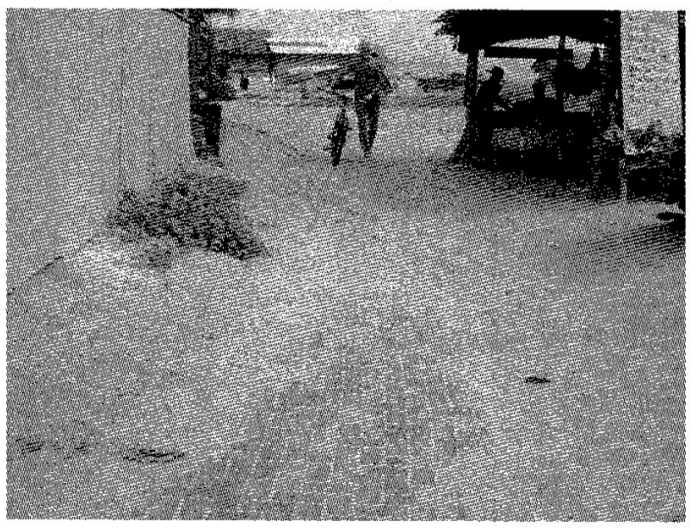

写真-5 公共エリア遊歩道上の砂の堆積

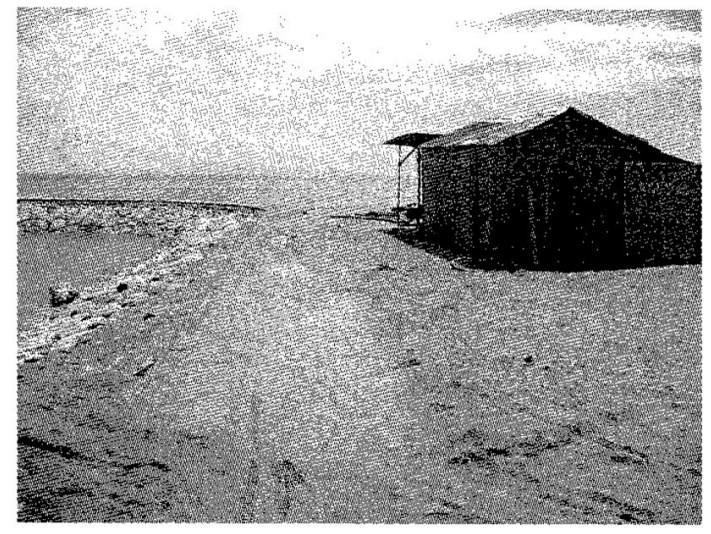

写真-6 養浜砂浜上での違法建築物の設置 